\title{
Kullanıcı Perspektifli Çok Kriterli Karar Verme ile Elektrikli Araçlarda Batarya Seçimi
}

\section{Multicriteria Decision Making Based on User Perspective for Battery Selection in The Electric Vehicles}

\author{
Mustafa Hamurcu1 iD, Emine Çakır ${ }^{1}$ iD, Tamer Eren *1 iD \\ ${ }^{1}$ Kırlkkale Üniversitesi, Mühendislik ve Mimarlık Fakültesi, Endüstri Mühendisliği Bölümü, 71450 Kırlkkale,TÜRKİYE
}

Başvuru/Received: $21 / 04 / 2021$

Kabul / Accepted: 10/06/2021

Çevrimiçi Basım / Published Online: 18/06/2021

Son Versiyon/Final Version: 18/06/2021

\section{$\ddot{O} \mathbf{z}$}

Geleneksel araçlar, iyi performans ve uzun menzil sağlamak için petrol ve türevi yakıtlardan yararlanmaktadır. Fakat bu araçlar, çevre kirliliğine sebep olması ve tükenmek üzere olan fosil yakıtlar nedeniyle dezavantajlara sahiptirler. Bu sebeplerden dolayı, alternatif yakıtlı araç teknolojileri gelişmektedir. Günümüzde, geliştirilen batarya teknolojileri ile çevre dostu olan elektrikli araçlar yaygınlaşmaktadır. Ancak batarya teknolojileri, batarya ömrü, deşarj oranı, nominal gerilim, spesifik enerji, dayanıklılık gibi özellikleri ile birbirinden farklılaşmakta ve çeşitlenmektedir. Bu çalışmada, enerji kaynağı olarak seçilecek olan batarya tipinin seçimi, çok kriterli karar verme yöntemleri olan analitik hiyerarşi prosesi (AHP) ve MOORA yöntemleri kullanılarak kullanıcı perspektifi bakımından yapılmıştır. Elektrikli araçların ve kullanılan çeşitli bataryaların tanıtıldığı çalışmada, kullanılan yöntemlerin sonuçları karşılaştırılmış ve en iyi alternatif olarak Li-ion batarya türü seçilmiştir.

\section{Anahtar Kelimeler}

"Batarya seçimi, elektrikli araçlar, AHP, MOORA"

\begin{abstract}
Traditional vehicles benefit from petroleum and derivative fuels to ensure good performance and long range. At the same time, they have disadvantages due to environmental pollution and fossil fuels that are about to run out. For these reasons, alternative fuel vehicle technologies are developing. Nowadays, electric vehicles are becoming more environmentally friendly with the developed battery Technologies. However, battery technologies are differentiated and diversified by their characteristics such as battery life, discharge rate, nominal voltage, specific energy and durability. In this study, the selection of the type of battery to be selected as the energy source is made in terms of user perspective by using analytical hierarchy process (AHP) and MOORA methods which are multicriteria decision making methods. Electric vehicles and various batteries are introduced in the study, the results of the methods used are compared and Li-ion battery type has been selected as the best alternative technology.
\end{abstract}

Key Words

"Battery selection, electric vehicles, AHP, MOORA" 


\section{Giriş}

Günümüzde elektrikli araçların (EA) önemi günden güne artmaktadır. Artan araç sayısı ve buna bağlı olarak fosil kaynaklı yakıtların gittikçe tükeniyor olması ve atmosferdeki karbondioksit gazı miktarının hızla artması sonucu ortaya çıkan çeşitli çevresel sorunlara neden olmaktadır. Tüm bu nedenler alternatif yakıt arayışına girilmesine sebep olmaktadır. Bu bakımdan önemli teknolojik gelişmelerden biri olan elektrikli araçlar bir çözüm olarak görülmektedir.

Batarya fiyatlarının düşmesi ve yeni batarya teknolojisi otomobil üreticilerinin daha uzun menzilli daha ucuz modeller üretmesini sağladığından, günümüzde giderek daha fazla kullanıcı elektrikli araçları tercih etmektedir (TEHAD, 2021). Yakın gelecekte, hareketliliğin büyümesi ve sürücüsüz araçların ortaya çıkışı, elektrikli araçları güçlü bir şekilde tamamlayarak, elektrikli araç pazarına giriş sürecini daha da hızlandırmaktadır. Buna ek olarak, yönetimler, çeşitli çevresel ve sosyo-ekonomik faydayı göz önünde bulundurarak uzun süredir EA satın alımlarını teşvik etmektedir. Yaygınlaşan elektrikli araçların benimsenmesine geçiş hızlanmaktadır, ancak yine de (i) uzun şarj süreleri ve (ii) toplu EA şarjı nedeniyle şebeke aşırı yüklemesi etrafında endişeler devam etmektedir (Sun vd., 2019).

Son yüzyılın başından bu yana, küresel enerji kıtlı̆̆ ve çevre kirliliği sorunu giderek daha ciddi hale gelmiştir. Bu duruma etki eden faktörlerden birisi de ulaşım için kullanılan araçlardır. EA'lar, temiz ve kirlilik içermeyen bir yeni ulaşım türü olarak, tüm toplumun dikkatini çeken enerji tasarrufu, çevre koruma ve sürdürülebilir kalkınma gereksinimlerini aynı anda karşılayabilen araçlar olarak ortaya çıkmaktadır. EA'lar için dezavantaj olarak görülen yetersiz menzil ve uzun şarj süreleri üzerinde durularak batarya teknolojilerinde önemli ölçüde gelişmeler kaydedilmiştir. Batarya ile çalışan elektrikli araçlar, kademeli olarak içten yanmalı motor tabanlı araçların yerini almaktadır. Ancak, daha iyi performans gösteren bataryaların geliştirilmesi hala devam ederken, bu süreç çok yavaş bir hızda gerçekleşmektedir. Hızlı şarj, uzun menzilli sürüş, uzun batarya ömrü ve düşük maliyet, gelişen batarya teknolojisinde karşılanması gereken katı gereksinimlerdir.

Tarihsel geçmişi eski olan elektrikli araçlar, şarj sürelerinin uzun olması ve performans seviyelerinin düşük olmasından dolayı gelişme gösterememişlerdir. Fakat alternatif enerji kaynaklarının bir çözüm olarak değerlendirildiği günümüzde elektrikli araçların tercih edilmesi ve elektrik enerjisinin kimyasal olarak depolanmasını sağlayan bataryalar büyük önem teşkil etmektedir. Batarya sistemi elektrikli araçlarda önemli bir etkendir. Elektrikli araçlarda kullanılan bataryaların yüksek enerji yoğunluğuna sahip olmasının yanı sıra, hızlı şarj edilebilmesi ve uzun ömürlü olması istenilen özelliklerden bazılarıdır. Ayrıca, elektrikli araçların menzilleri batarya kapasiteleri ile doğru orantılıdır.

Günümüzde popüler olan elektrikli araçların tarihi aslında 1800'lü yılların başına kadar dayanmaktadır. Stratingh tarafından 1835 yılında ilk elektrikli araç modeli oluşturulmuş ve ilk fren sistemi 1897 yılında bulunmuştur. Ayrıca fren sistemi elektrikli bir araca uygulanarak menzili artırılmışır (Solera, 2001). Daha sonra maksimum $6,4 \mathrm{~km} / \mathrm{h}$ hızla yol alabilen elektrikli lokomotif Davidson tarafından üretilmiştir.1900'lü yıllara gelindiğinde Electroautomobile ve 1903 yılında hem elektrik hem de benzinle çalışan hibrit elektrikli araç modeli ortaya koymak için çalışılmış ve sonuçta 1916 yllında hibritli elektrik araç üretilmiştir (Huo vd., 2015). Devam eden yıllarda elektrikli araçlara olan ilgi azalırken motorlu (içten yanmalı) araçlara ise 1920-1960 yılları arasında ilgi artmıştır. Ayrıca 1935'li yıllarda EA'lar piyasada neredeyse hiç bulunmamıştır. 1990'dan itibaren batarya teknolojisinin geliştirilmeye çalışılmasıyla birlikte birçok firma EA geliştirmeye başlamıştır.

Elektrikli araçların birçok avantajı bulunmaktadır. Örneğin: Motorda yağ değişimine gerek yoktur ve frenleme esnasında kaybedilen enerjinin kullanılmasıyla tekrar bataryada depolanmasını sağlanmaktadır. Dolayısıyla bu araçların elektriğe bağlanarak şarj edilmesi gibi bir gereksinim azdır (Sayın ve Yüksel, 2011; Güner, 2013; Khaligh ve Zhihao, 2010). Ayrıca elektrikli araçlar içten yanmalı motorlara göre çok daha az parçadan oluşan teknik altyapı sayesinde çok daha geniş iç mekân sunmaktadır. Batarya ve bakımları diğer motorlu araçlara göre çok daha kolay ve düşük maliyetlidir. Daha hızlı, daha sessiz ve daha ferah olmasının yanı sıra düşük maliyetle cazip bir finansal çözüm oluşturması da tercih edilme sebeplerindendir. Elektrikli araçların kullanımındaki artış, yenilenemez enerji kaynakları ve yakıt maliyetlerini düşürmektedir (Von vd., 2015). Bu gibi avantajlardan dolayı elektrikli araçlara olan ilgi gittikçe artmaktadır. Beraberinde gelişmekte olan batarya teknolojileri de elektrikli araçların gelişiminde büyük paya sahiptir. (Frieske, 2013). Trafikte elektrikli araçların kullanmanın avantajları, tekerleklere iletilen elektrik motorunun yüksek torku ve içten yanmalı motorlu araçlara göre daha yumuşak hızlanma (ve yavaşlama). Ayrıca elektrikli araçlar elektrik motorunu çalıştırırken gürültü yaymazlar ve kirletici emisyonlar üretmezler. Bu bakış açıları, EA'ları kentsel alanlarda kullanılacak ideal araçlar haline getirmektedir. Ancak bu avantajların yanı sıra, EA'arın kullanmanın bazı dezavantajları vardır:

- Yüksek üretim maliyetleri.

- Küçültülmüş toplam boyut

- Sinırlı özerklik ve hız.

- Yüksek şarj süreleri ve özel şarj yerlerine ihtiyaç.

- Elektrik motoru gürültüsünün olmaması trafik kazalarına (işitme engelli kişiler, yayalar, bisikletliler vb.) neden olabilir.

Elektrikli araç üreticileri, yalnızca performans faktörlerini göz önünde bulundurarak bataryayı seçme eğilimindedirler; enerji yoğunluğu ve güç, ayrıca güvenlik, güvenilirlik (arızasız çalışma) ve maliyet gibi diğer önemli özellikleri de göz önünde bulundururlar. Ancak, 
üreticilerin karar verme veya seçim için bir aracı yoksa en iyi bataryayı seçmek kolay bir iş değildir. Bu noktada çok kriterli karar verme (ÇKKV) araçları önemli rol oynamaktadır. ÇKKV, çok sayıda faktöre dayalı olarak çeşitli alternatifler arasından en iyisinin seçiminin sağlanması için karmaşık problemlerle ilgilenir. Karar vericiler optimal bir çözüm bulmak isteyeceklerdir ve bu sadece tek kriterlere dayalı karar verme durumları için elde edilebilir. Genel olarak, belirli durumlar için alınan kararlar çatışmalar içerir. Bazı endüstriyel durumlarda, zayıf veya çelişkili kararların sonuçları güvenli olmayan durumlara yol açacaktır. Dolayısı ile güvenli batarya teknolojisinin seçimi de EA'ların üretiminde kritik bir karar sürecidir.

Elektrikli araçlarda kullanılacak olan batarya seçiminde karar verme süreci, ÇKKV için uygun bir alandır çünkü batarya sistemleri çok sayıda faktör ve çeşitlilik içermektedir. Ayrıca gelişmekte olan ve ilgi gören elektrikli araçlar için dikkate alınması gereken önemli detaylardandır. Piyasada çok sayıda batarya çeşitlerinin bulunması ve hala istenilen düzeyde olmaması, karar verme süreci için çok karmaşıktır. Bu sebeple elektrikli araçlarda batarya seçimi, birden fazla amacı bir arada değerlendirerek karmaşık süreçleri daha anlaşı1ır bir biçimde çözümleyebilmek için tercih edilmektedir (Kerem, 2014).

Bu çalışmada alternatif yakıtlı ulaşım araçlarından elektrikli araçların batarya seçiminde ÇKKV yöntemlerinden AHP, MOORA ve bütünleşik AHP-MOORA seçim sürecini içermektedir. AHP yöntemi basit ve temel matematiksel hesaplamaları içermesi, daha anlaşlır olması, değerlendirme kriterlerinin önem seviyelerinin görülebilmesi nedenlerinden dolayı; MOORA yöntemi ise temel matematiksel hesaplamalar içermesi ve kısa sürece çözüm sunması nedenlerinden dolayı kullanılmıştır.

Çalışmanın ikinci kısmında elektrikli araçlar ve bataryalarıyla alakalı literatür taraması yapılmıştır. Üçüncü bölümde, elektrikli araçlar ve batarya teknolojilerinden bahsedilmiştir. Dördüncü bölümde ise ÇKKV yöntemlerinden olan AHP ve MOORA yöntemleri sırasıyla anlatılmıştır. Beşinci bölümde batarya seçimi uygulaması yapılmıştır. Son kısım olan altıncı bölümde, sonuç ve önerilere yer verilmiştir

\section{Literatür Araştırması}

Tüm Araçların neden olduğu hava kirliliği ve fosil yakıtların tükenmesi alternatif yakıtlı araçların gelişiminin hızlanmasında önemli iki etmendir ve gün geçtikçe fosil yakıtların çevre kirliliğine neden olmasından dolayı elektrikli araçlar alternatif bir seçenek haline gelmiştir (Xiong vd., 2018). Elektrikli araçlar sera gazının azaltılmasında önemli rol oynamaktadır (Bulach vd., 2018; San vd., 2011). Diğer araçlarla karşılaştıııldığında, elektrikli araçlar çevreye hiç atık gaz salımı gerçekleştirmiyor. Bu sayede neredeyse yüzde 100 çevrecidir. Güneş ya da rüzgâr gibi enerji kaynaklarından elektrikli otomobil şarj ediliyorsa o zaman çevrecilik oranı maksimum seviyede gerçekleşmektedir.

Günümüzde elektrikli araçlar, otomotiv endüstrisinde önemli bir pazara sahiptir ve birçok firma elektrikli araçlara yatırım yapmakta ve üretim süreçlerini elektrikli araçlar yönünde evirmektedir. Bataryalı elektrikli araçlar, yüksek kapasiteli bataryalı ve elektrik motora sahip tamamen elektrikli araçlardır. Benzinli motoru, yakıt hücresi ve yakıt deposu yoktur. Elektrik motorunu ve tüm yerleşik elektronikleri çalıştırmak için tüm gücü bataryadan alır. Bu elektrikli araçları şarj etmenin tek yolu, harici bir kaynaktan elektrik kullanmaktır. Bileşenlerin hasar görmesi ve bozulması nedeniyle pil performansı önemli ölçüde düşebilir. Sınırlı sürüş menzili ve çok yüksek satın alma maliyeti, düşük maliyetli elektrikli araçlar üretmenin önündeki kritik engellerdir. Elektrikli bir aracın başarısı veya başarısızlığı, bataryanın performansına bağlıdır. Mevcut batarya teknolojilerinin dezavantajlarını ortadan kaldırmak için dünyanın dört bir yanındaki Ar-Ge kuruluşları, otomotiv şirketleri ve üniversiteler EA uygulamaları için yeni teknolojiler geliştirmeye çalışıyor. Günümüzde de çeşitli batarya teknolojileri, elektrikli araçlarda görülmektedir. Bu kadar ilgi gören elektrikli araçların batarya seçimine dikkat edilmektedir. Elektrikli araçlarda yeniden doldurulabilir batarya teknolojileri bulunmaktadır ve tercih edilen bataryalar ömürlük değildir. Batarya ömrünün kısa olması ve birkaç yıl içerisinde değişim gerektirmesi araç maliyetlerini arttırmaktadır (Kerem, 2014). Bataryalar doğru kullanılmamış veya geri dönüşümsüz olduğu takdirde sadece kaynak israfina neden olmayıp, çevre kirliliğine de neden olmaktadır (Ordonez vd., 2016). Bununla birlikte araçlarda kullanılacak olan bataryalar geri dönüşüm esaslı olarak gelişme göstermektedir. Elektrik motorunun ihtiyacı olan elektrik enerjisi bataryalardan sağlanmaktadır (Öztürk, 2018; Chan, 2013). Elektrikli araçlarda bataryanın uzun menzilde yetersizliği ve enerjiyi depolama bir sorun olmakla birlikte, EA'lara olan ilginin azalmasına sebep olmaktadır (Huo vd, 2015). Bu sebeple elektrikli araçlarda en önemli sorunlardan biri batarya seçim problemidir. Elektrikli araçların kullanımındaki artış, yenilenemez enerji kaynakları ve yakıt maliyetlerini düşürmektedir (Von vd., 2015).

Elektrikli araçlarda yaygın olarak Pb-asit (Kurşun-Asit), Ni-Cd (Nikel Kadmiyum), Ni-MH (Nikel Metal Hidrat) ve Li-ion (Lityum İyon) pilleri tercih edilmektedir. Son zamanlarda bunlara ilave olarak Alüminyum-Hava ve Çinko-Hava bataryaları geliştirilmiştir Bowkett vd., 2013). Lityum iyon piller yüksek anma voltajı, yüksek enerji yoğunluğu, uzun ömrü ve hafıza etkisinin bulunmaması gibi önemli avantajlarından dolayı diğer pil teknolojilerine kıyasla en çok tercih edilen batarya çeşididir (Vu vd., 2013). Ancak lityum iyon piller henüz istenilen düzeye ulaşmadığı için gelişim göstermeye devam etmektedir.

Elektrikli araçlarda kullanılan bataryalar üzerine literatür de birçok çalışma vardır. $\mathrm{Bu}$ çalışmalar bataryaların birbiriyle karşılaştırılması, batarya tasarımı, batarya şarj kontrol yöntemleri (Raslavicius vd., 2015; Erhan vd., 2013), batarya şarj cihazlarının yerleşim çalışmaları (Sierzchula vd., 2014), batarya teknolojilerinin geliştirilmesi (Demir ve Aküner, 2018; Dikmen, 2018) ve daha uzun menzilde verimli çalışmasına yönelik yapılan çalışmalardır. Tüm bu çalışmalar elektrikli araçların geliştirilmesi için altyapının oluşturulması ve elektrikli araçlarda kullanılmak üzere seçimi yapılacak olan batarya sistemlerine zemin hazırlamaktadır (Raslavicius vd., 2013; Battery University, 2014). Elektrikli araç ve batarya teknolojileri alanında yapılan çalışmalar Tablo 1' de gösterilmiştir. 
Tablo 1. Elektrikli araç ve batarya teknolojisi alanında yapılan çalışmalar

\begin{tabular}{|c|c|c|c|c|c|}
\hline Nu. & Yazar/lar & Yıl & $\begin{array}{c}\text { Karar } \\
\text { Problemi }\end{array}$ & Çalışmanın amacı & Teorik/Uygulama \\
\hline 1 & Aktaş vd. & 2021 & --- & Batarya yönetim sistemi tasarımı & --- \\
\hline 2 & Celen ve Kaba & 2021 & $\begin{array}{l}\text { Batarya } \\
\text { teknolojisi }\end{array}$ & $\begin{array}{c}\text { Elektrikli araçlarda kullanılan } \\
\text { silindirik lityum iyon bataryaların } \\
\text { soğutulmasının parametrik } \\
\text { incelenmesi }\end{array}$ & Teorik \\
\hline 3 & Hamurcu ve Eren & 2020 & $\begin{array}{l}\text { Ulaşım } \\
\text { planlama }\end{array}$ & Elektrikli otobüs seçimi & Uygulama (AHP-TOPSIS) \\
\hline 4 & Kaymaz ve Demir & 2020 & $\begin{array}{l}\text { Araç } \\
\text { teknolojisi }\end{array}$ & $\begin{array}{l}\text { Elektrikli Otomobiller için Çekiş } \\
\text { Motor Tip Seçimi. }\end{array}$ & --- \\
\hline 5 & Gavcar ve Kara & 2020 & Ulaşım & Elektrikli Otomobil Seçiminde & Entropi-TOPSIS \\
\hline 6 & Sun vd. & 2019 & $\begin{array}{l}\text { Stratejik } \\
\text { planlama }\end{array}$ & $\begin{array}{c}\text { Batarya değişimi ve şarj etme } \\
\text { stratejileri }\end{array}$ & --- \\
\hline 7 & Demir ve Aküner & 2018 & $\begin{array}{c}\text { Enerji } \\
\text { kazanımı }\end{array}$ & $\begin{array}{l}\text { Frenleme ile kaybedilen enerjinin geri } \\
\text { kazanılması değerlendirmeleri }\end{array}$ & Uygulama (Taguçi) \\
\hline 8 & Cano vd. & 2018 & --- & $\begin{array}{l}\text { Gelişen batarya teknolojisinde, araba } \\
\text { pazarının değerlendirilmesi }\end{array}$ & Teorik \\
\hline 9 & Öztürk & 2018 & --- & $\begin{array}{l}\text { Taşımacılıkta elektrikli araç } \\
\text { kullanımının incelenmesi }\end{array}$ & Teorik \\
\hline 10 & Tarlak ve İşen & 2018 & --- & $\begin{array}{l}\text { Elektrikli araçlar ve batarya şarj } \\
\text { sistemlerinin değerlendirilmesi }\end{array}$ & Teorik \\
\hline 11 & Güven ve Rende & 2017 & $\cdots$ & $\begin{array}{l}\text { Elektrikli araç tasarımında malzeme } \\
\text { seçimi öneminin değerlendirilmesi }\end{array}$ & Teorik \\
\hline 12 & Ogura ve Kolhe & 2017 & $\cdots$ & $\begin{array}{c}\text { Elektrikli araçlar için batarya } \\
\text { teknolojilerinin değerlendirilmesi }\end{array}$ & Teorik \\
\hline 13 & Sarıkurt ve Balıkç & 2017 & --- & Batarya çalışma süresini uzatmak & Deneysel \\
\hline 14 & Ahmadi vd. & 2016 & $\cdots$ & $\begin{array}{l}\text { Hızlı şarj istasyonları üzerine bir } \\
\text { inceleme }\end{array}$ & Teorik \\
\hline 15 & Debreceni vd. & 2016 & $\begin{array}{l}\text { Bataryalar } \\
\quad \text { için } \\
\text { istasyonlar }\end{array}$ & $\begin{array}{l}\text { Elektrikli araçlar için batarya } \\
\text { sistemleri tasarımı gerçekleştirme }\end{array}$ & Uygulama \\
\hline 16 & Guo ve Zhao & 2015 & Yer seçimi & $\begin{array}{l}\text { Elektrikli araç şarj istasyonunun } \\
\text { optimum yer seçimini belirleme }\end{array}$ & $\begin{array}{l}\text { Uygulama (Bulanık } \\
\text { TOPSIS) }\end{array}$ \\
\hline 17 & Sergio ve Florın & 2015 & --- & $\begin{array}{l}\text { Biyolojık sistemlerın incelenmesı ve } \\
\text { bataryaların çevre üzerindeki } \\
\text { etkilerinin değerlendirilmesi }\end{array}$ & Teorik \\
\hline 18 & Ustabaş & 2014 & $\cdots$ & $\begin{array}{l}\text { Mikro ve Makro etkileri yönünden } \\
\text { elektrikli araçların değerlendirilmesi }\end{array}$ & Teorik \\
\hline 19 & Uçarol vd. & 2014 & .... & $\begin{array}{c}\text { Hibrid ve elektrikli araçlar için } \\
\text { ulaşımda enerji verimliliğinin } \\
\text { değerlendirilmesi }\end{array}$ & Teorik \\
\hline 20 & Özkop & 2013 & $\begin{array}{l}\text { Batarya } \\
\text { tasarımı }\end{array}$ & $\begin{array}{c}\text { Elektrikli araçlar için şarj cihazı } \\
\text { tasarımı }\end{array}$ & Uygulama (Benzetim) \\
\hline 21 & Yazıcı ve Özdemir & 2013 & $\cdots \cdots$ & $\begin{array}{c}\text { Elektrikli araç şarj yöntemlerinin } \\
\text { değerlendirilmesi }\end{array}$ & Teorik \\
\hline 22 & Satılmış ve Meşe & 2011 & $\begin{array}{l}\text { Batarya } \\
\text { tasarımı }\end{array}$ & $\begin{array}{l}\text { Verimli ve optimum şarj sağlayan } \\
\text { batarya şarj cihazlarının tasarlanması }\end{array}$ & Teorik \\
\hline 23 & Gören & 2011 & $\ldots$ & $\begin{array}{l}\text { Hibrid ve elektrikli araçların sağladığ } 1 \\
\text { enerji tasarrufu ve çevreci } \\
\text { operasyonlarının belirlenmesi }\end{array}$ & Teorik \\
\hline 24 & Hofman ve Dai & 2010 & $\ldots$ & $\begin{array}{l}\text { Elektrikli araç için enerji verimliliği } \\
\text { analizi değerlendirmesi }\end{array}$ & Teorik \\
\hline 25 & Tuncay ve Üstün & 2004 & $\cdots$ & $\begin{array}{l}\text { Otomotiv elektroniğindeki } \\
\text { gelişmelerin incelenmesi }\end{array}$ & Teorik \\
\hline
\end{tabular}


Elektrikli araçlar ile ilgili geçmişten günümüze literatürde yapılmış birçok çalışma vardır. Yapılan bu çalışmalar sayesinde elektrikli araçlar hakkında daha fazla bilgi edinmekle birlikte avantaj ve dezavantajlarını karşılaştırma firsatı bulmaktayız. Bunun beraberinde gelişmekte olan batarya teknolojileri ve batarya şarj istasyonları elektrikli araçların ilerleme sürecine önemli ölçüde katkı sağlamaktadır. Bu çalışmanın literatüre katkısı ise elektrikli araç teknolojisinin gelişmesinde önemli bir faktör olan batarya sistemlerinin seçimi hakkında yapılan birkaç çalışmadan biri olmasıdır.

\section{Elektrikli Araçlarda Batarya Teknolojisi}

Elektrikli araçlar, içten yanmalı motorlu araçlar, hibrit elektrikli araçlar ve tümü elektrikli araçlar olmak üzere enerji kaynağı ve motor tahrik yöntemine göre üç grup altında sınıflandırılmıştır (Gears educational system, 2014). Elektrikli aracın genel çalışma prensibi: elektrik motorunun ihtiyacı olan enerji bataryalardan sağlanmaktadır ve motorun hareketi ise aktarma organı ile tekerlere iletilmektedir (Elbir and Koca, 2013). Bu araçlarda kullanılmak üzere batarya teknolojileri bulunmaktadır. Bataryaların enerji kapasitesinin arttırılması amacıyla araştırmalar devam etmektedir. Farklı malzemeler geliştirilerek batarya ömrü ve kapasitesi iyileştirilmeye çalışılmaktadır.

Yeterli şarj olduğunda batarya da mevcut olan motor, batarya gücünü kullanarak aracın hareket etmesini sağlar. Batarya hızlı bir şekilde şarj edilmelidir, fakat deşarj oranı daha az olmalıdır. Batarya şarj cihazından istenen bazı özellikler; yüksek verimlilik, uygun maliyet, aşırı akım, gerilim ve şarj-deşarj durumu gibi bazı kriterlerdir. Temel olarak yüksek güç uygulamaları için Li-ion, Ni-MH, Ni-Cd ve $\mathrm{Pb}$-asit bataryalar kullanılır. Bundan dolayı elektrikli araç uygulamaları için uygun bataryalar olarak tercih edilmiştir. Bataryalarda bulunan pil özellikleri enerji yoğunluğu, elektriksel verimlilik, dayanıklılık, enerji/çevrim, spesifik enerji, deşarj oranı ve nominal gerilim olarak belirlenmiştir. Elektrikli araçlarda yaygın olarak kullanılan pil teknolojileri ve özelikleri Tablo 2'de gösterilmiştir (Yong, 2016; Keçek ve Yüksel, 2016).

Tablo 2. Batarya Teknolojileri

\begin{tabular}{cccccc}
\hline Özellikleri & Birim & Li-ion & Ni-MH & Ni-Cd & Pb-asit \\
\hline Spesifik enerji & Wh/kg & 180 & 70 & 50 & 35 \\
Enerji yoğunluğu & Wh/I & 180 & 140 & 100 & 70 \\
Elektrik verimliliği & $\%$ & 85 & 66 & 90 & 90 \\
Deşarj oranı & $\% /$ ay & 5 & 30 & 10 & 20 \\
Nominal gerilim & $\mathrm{V}$ & 3.6 & 1.2 & 1.2 & 2.0 \\
Enerji/çevrim & $\mathrm{Wh}$ & 8.6 & 7.5 & 4.5 & 24 \\
Dayanıklılık & cycles & 1200 & 1000 & 2000 & 800 \\
\hline
\end{tabular}

Değerlendirme kriterleri olarak batarya seçiminde önemli 7 faktör belirlenmiştir; spesifik enerji (K1), enerji yoğunluğu (K2), elektrik verimliliği (K3), deşarj oranı (K4), nominal gerilim (K5), enerji/çevrim (K6) ve dayanaklılık (K7).

$\mathrm{Pb}$-asit piller birçok uygulama ve araçta kullanılmakta olan yaygın bir pil teknolojidir. Bu piller yüksek güç uygulamaları için tasarlanmıştır. Aynı zamanda ucuz ve güvenilirdir. Yüksek deşarj akımı, düşük özboşalım, hafıza etkisinin bulunmaması, düşük özgül enerjiye ve sıcaklığa karşı hassas bir pil çeşididir. Dolayısıyla, bu piller kullanılmadıkları zaman pil ömürleri düşmektedir. Pb-asit bataryadan daha yüksek enerji yoğunluğuna sahip, güvenli ve ucuz bir pil teknolojidir. Ayrıca zayıf şarj/deşarj verimi, yüksek özboşalım ve hafıza etkili olması da dezavantajlarındandır (Keçek ve Yüksel, 2016). Ni-MH pilleri eşdeğer Ni-Cd hücresine göre 2-3 kat daha fazla kapasiteye sahiptir ve Ni-MH pil teknolojisi Ni-Cd pillerin dezavantajlarına alternatif olarak geliştirilmiştir. Ni-MH ile ilgili dezavantajlar, yüksek öz deşarj oranı, daha yüksek sıcaklıkta ısı üretimi ve daha yüksek maliyete sahip olmasıdır. Nominal voltaj değerleri eşit olmasıyla birlikte nikel metal hidrat piller daha yüksek enerji yoğunluğuna sahiptir (Keçek ve Yüksel, 2016). Li-ion piller, düşük toksit, yüksek kapasite ve ucuz olması avantajları nedeniyle diğer materyallere göre lityum metal oksitler kullanılmaktadır. Tüksek enerji verimliliğine sahip olan Li-ion aküler, daha yüksek enerji barındırırlar. Li-ion pilleri en çok tercih edilen pil çeşidi olup yüksek enerji yoğunluğuna sahiptir (Keçek ve Yüksel, 2016). Elektrikli araçlarda kullanılan birçok batarya çeşidi bulunmaktadır. Farklı anma voltajı ve enerji yoğunluğuna sahip batarya teknolojileri gelişim göstermektedir. Yaygın olarak kullanılan dört pil haricinde; LiPo, LiFePO4, Li-S, Zn-air, Zebra vb. gibi henüz araştırma aşamasında olan batarya teknolojileri de bulunmaktadır (Yong, 2015).

\section{Yöntemler}

Ulaşım araçlarının tasarımı ile ilgili ortaya çıkan karmaşık sorunları çözmek için, ÇKKV yöntemlerinin uygun araçlardan biri olduğu görülmektedir. ÇKKV temelde çok çeşitli metodolojileri içeren yöneylem araştırmasından doğmuştur, ancak yine de diğer disiplinlerde rasyonel bir temele sahiptir. ÇKKV teknikleri, tarımsal kaynak yönetimi, eğitim, ulaşım, yatırım, çevre, savunma, sağlık hizmetleri vb. ile ilgili özel sektör kararlarının ve kamu sektöründe geniş uygulama alanı bulmuştur. ÇKKV yöntemleri ile elektrikli araçlarda batarya seçimine yönelik yapılan bu çalışmada, AHP, MOORA ve AHP-MOORA olmak üzere üç farklı uygulama yapılmıştır. Karar verme süreçlerinde AHP ve MOORA yöntemleri ayrı ayrı kullanıldığı gibi bütünleşik (AHP-MOORA) uygulamaları da yapılmıştır. 


\subsection{Analitik Hiyerarși Prosesi (AHP)}

AHP, Saaty tarafından geliştirilen analitik bir karar verme sürecidir ve süreç basit matematiksel hesaplamaları içerir (Saaty 1990). AHP, ikili karşılaştırmaya dayalı yapılandırılmış, alternatiflerin kriterlerinin ağırlıklarını ve önceliklerini belirlemek için geniş çapta uygulanan çok kriterli bir karar verme yöntemidir. Problemin hedefi, değerlendirme kriterleri ve alternatiflerden oluşan karar hiyerarşisi doğrultusunda, karmaşık karar problemlerinin çözümünde kullanılmaktadır. AHP, problemi hiyerarşik bir şekilde, hedeften ölçütlere, alt ölçütlere ve ardışık düzeylerde alternatiflere inerek yapılandırır (Saaty, 1990). Hiyerarşi, uzmanlara bağlamın doğasında bulunan karmaşık ilişkilerin genel bir görünümünü sağlar ve aynı seviyedeki unsurların karşılaştırılabilir olup olmadığını değerlendirmelerine yardımcı olur. Öğeler daha sonra ağırlıklarını elde etmek için 9 seviye ölçeğine göre ikili olarak karşılaştırılır. AHP uygulama adımları sırası ile verilmiştir;

\subsubsection{Hiyerarşik yapının oluşturulması}

Karar hiyerarşisi hedef, kriterler $(\mathrm{K} 1, \mathrm{~K} 2, \mathrm{~K} 3, \ldots \mathrm{Kn})$ ve alternatifler $\mathrm{A} 1, \mathrm{~A} 2, \ldots$, An) olarak 3 seviyeden oluşmaktadır. Gerek duyulduğunda kriterler alt kriterlere de ayrılabilmektedir. Hiyerarşik yapı Şekil 1'deki gibi kurulmuştur.

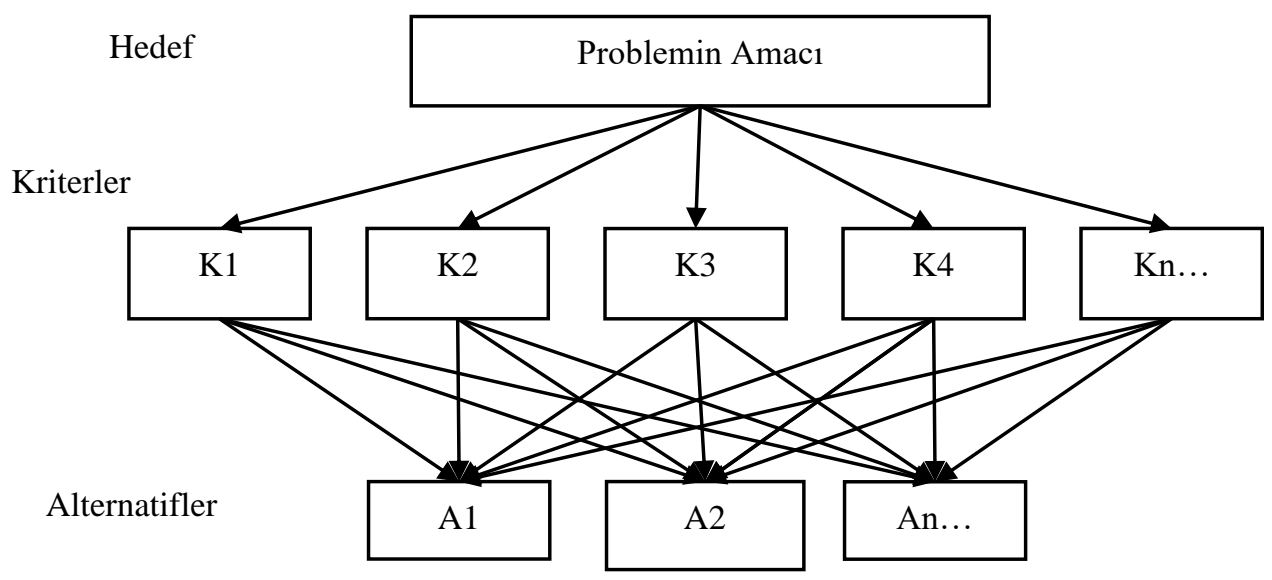

Şekil 1. AHP karar hiyerarşisi

\subsection{2. İkili karşılaştırma matrisleri ve üstünlük belirlenmesi}

İkili karşılaştırmalar önce kriterin kendi aralarında ve daha sonra her kriter için alternatifleri kendi aralarında ikili karşılaştırmalara tabi tutulur. Karşılaştırmalarda Tablo 3'teki Saaty'nin (Saaty, 1990) önem skalası değerleri kullanılarak (nxn) ikili karşılaştırma matrisi oluşturulur.

Tablo 3. Saaty önem derece tablosu

\begin{tabular}{cc}
\hline Önem Derecesi & Açılama \\
\hline $\mathbf{1}$ & İki faktör arası "eşit önemli" ise \\
$\mathbf{3}$ & Biri diğerine göre "orta derecede" daha \\
$\mathbf{5}$ & önemli ise \\
$\mathbf{7}$ & "Kuvvetli düzeyde" önemli ise \\
$\mathbf{9}$ & "Çok kuvvetli düzeyde önemli" ise \\
$\mathbf{2 , 4 , 6 , 8}$ & "Aşırı derecede önemli" ise \\
\hline
\end{tabular}

\subsection{3. Özvektör değeri ve tutarlılık oranı hesaplanması}

İkili karşıllaştırma matrisinin normalleştirilmesi ve satır ortalamalarının alınması özvektör elde edilir (Özvektörü $-\mathrm{W}=\left(\mathrm{w}_{1}, \mathrm{w}_{2}, \ldots, \mathrm{w}_{\mathrm{n}}\right)$. Özvektör (w) değeri (1) numaralı formül ile hesaplanır.

$\mathrm{W}=\frac{\sum_{j=1}^{n} c_{i j}}{n}$ 
Özvektör değerinin hesaplanmasının ardından yapılan hesaplama ve karşılaştırmaların tutarlı olup olmadığı test edilir. Tutarılık oranı (CR)'nın test edildiği bu süreçte, formül (2) kullanılır. Bu formülde tutarlılık göstergesi (CI), formül (3) ve (4) kullanılarak hesaplanır. Rassallık indeksi (RI) ise Tablo 4'ten okunur (Elbir ve Koca, 2013).

$C R=\frac{C I}{R I}$

Tutarlılık göstergesinin (CI) hesaplanmasında, (3) numaralı formül kullanılır.

$C I=\frac{\Lambda_{\max }-n}{n-1}$

$C I$ değeri için ayrıca en iyi öz değerin $\left(\lambda_{\max }\right)$ hesaplanmasında (4) numaralı formül kullanılır.

$\Lambda_{\max }=\frac{\sum_{i=1}^{n} E_{i}}{n}$

Formül (2) ‘de yer alan rassal indeks (RI) değeri (Palaz ve Kovacı, 2008) Tablo 4'de gösterilmektedir.

Tablo 4. RI Değerleri

\begin{tabular}{cccccccc}
\hline $\mathbf{N}$ & $\mathbf{R I}$ & $\mathbf{N}$ & $\mathbf{R I}$ & $\mathbf{N}$ & $\mathbf{R I}$ & $\mathbf{N}$ & $\mathbf{R I}$ \\
\hline $\mathbf{1}$ & 0 & $\mathbf{4}$ & 0,90 & 8 & 1,41 & 11 & 1,51 \\
$\mathbf{2}$ & 0 & $\mathbf{5}$ & 1,12 & 9 & 1,45 & 12 & 1,48 \\
$\mathbf{3}$ & 0,58 & $\mathbf{6}$ & 1,24 & 10 & 1,49 & 13 & 1,56 \\
\hline
\end{tabular}

\subsubsection{Alternatiflerin önem sıralamasının bulunması}

Kriterlerin değerlendirmesi için uygulanan adımları alternatiflerin değerlendirmesi için de uygulanır ve her kriter için alternatifler ikili karşılaştırmalara tabi tutulur. Yapılan karşılaştırmalar ve basit matematiksel işlemler sonucunda kriter ve alternatiflerin ağırlıkları ayrı ayrı elde edilir. $\mathrm{Bu}$ ağırlıkların matris çarpımları sonucunda alternatiflerin önem seviyeleri elde edilir. Bu değerler büyükten küçüğe sıralanarak, en büyük değer, birinci seçimi oluşturacak şekilde devam eder.

AHP yöntemi birçok karar probleminde seçim ve değerlendirme amacıyla uygulanmıştır. Denizcilik alanında (Adıgüzel, 2009); personel seçimi (Yılmaz ve Dağdeviren, 2010); program seçimi problemi (Tunca vd., 2015); trafik kazaları arasındaki ilişkinin analizi (Kılınçcı ve Önal, 2011) AHP yöntemiyle yapılmıştır. Tedarikçi seçimi (Ömürbek vd., 2013); hassas bölgelerin analizinde (Çellek, 2013); proje seçimi (Dinç vd., 2018) ve ulaşım planlama (Taş vd., 2017) konularında AHP yöntemi kullanılmıştır. AHP yöntemi diğer ÇKKV yöntemleri ve matematiksel modeller ile de karma olarak kullanılmıştır (Hamurcu ve Eren, 2020; Gür vd., 2017; Hamurcu ve Eren, 2017; Hamurcu vd., 2017; Deringöz vd., 2021).

\subsection{MOORA Yöntemi}

MOORA (Multi Objective Optimization on the Basis of Ratio Analysis) ilk kez 2006 y1lında Brauers ve Zavadskas tarafindan uygulanmıştır. Bu yöntemin en önemli avantajı: alternatifler ve amaçlar arası bütün etkileşimleri aynı anda dikkate alarak, tarafsız ve bütünleşik bir karar verme sürecinin içermesidir (Brauers vd., 2010). Literatürde bulunan MOORA metotları; Oran yöntemi, Referans noktası yaklaşımı, Önem katsayısı yaklaşımı, Tam çarpım yaklaşımı ve Multimoora yaklaşımı olarak verilmiştir.

$\mathrm{Bu}$ metotlar temel olarak birinci sırada yer olan oran metodu ile başlar. MOORA kendi başına bir metot olmayıp; farklı MOORA metotları sonucu farklı sıralamalar ortaya çıkmaktadır. Birden fazla metot olması, son bir değerlendirme yapılmasını sağlamakta ve mevcut ÇKKV metotları arasında güvenilirlik açısından en üst seviyeye taşımaktadır.

Aşama 1. Amaçların Belirlenmesi ve Alternatiflerin Performans Değerlerinin Belirlenmesi

Başlangıç matrisinin oluşturulması, alternatiflerin ve amaçların performans değerlerinin belirlenmesiyle başlar. MOORA yönteminin ilk adımında kullanılan başlangıç matrisi tablosu oluşturulur. Belirtilen matrise ilişsin ifadeler ( $\mathrm{x}_{\mathrm{ij}}$ : i. alternatifin $\mathrm{j}$. ölçüt açısından performans ölçüm değeri, i: alternatif j: nitelik ya da ölçüt, m: toplam alternatif sayısı, n: toplam nitelik ya da ölçüt ) şeklinde belirtilir. 


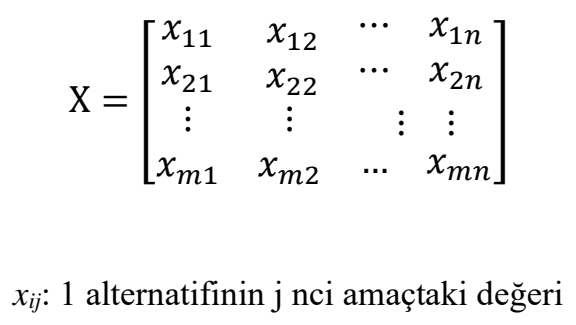

Aşama 2. Matrisin Normalleştirilmesi

Formül (5) kullanılarak alternatif değerlerin performans değerleri, performans değerlerinin karesinin toplamına bölünerek karekökünün alınması ile hesaplanır.

$X_{i j}^{*}=\sqrt{\frac{x_{i j}}{\sum_{i=1}^{m} x_{i j}^{2}}}$

Sonrasında tüm alternatifleri temsil edecek olan bir payda değeri hesaplanır. Burada;

$X_{i j}^{*}$ : i. Alternatifin, j. amaca göre normalleştirilmiş performans değerini göstermektedir. $\left(-1<=x_{i j}<=1\right)$

Aşama 3. Normalleştirilmiş matrisin en büyükleme performans değerleri toplamından en küçükleme performans değerleri toplamının çıkarılması

MOORA oran metodu ile çözüm hesaplaması (6) numaralı formül ile gösterilir.

$$
y_{i}=\sum_{j=1}^{g} x_{i j}-\sum_{j=g+1}^{n} x_{i j}
$$

Eşitlik (6)'da;

$\mathrm{g}$ : en büyüklenecek faktör sayısı

(n-g): en küçüklenecek faktör sayısı

$y_{i}$ : i. alternatifin tüm amaçlara göre normalleştirilmiş değerleridir.

Sonuçta bulunan yi değerleri küçükten büyüğe doğru sıralanması ile birinci sıradaki alternatif en iyi seçenek olarak kabul edilir.

MOORA referans metodu ile çözüm hesaplaması (7) numaralı formül ile gösterilir.

$\max \left\{\min \left|r_{i}-\mathrm{x}_{\mathrm{ij}}\right|\right\}$

Turizm sektörü ile ilgili sorunların MOORA yöntemi kullanılarak çözümü açısından bir model önermektedir (Mandal ve Sarkar, 2012). MOORA yöntemi ilk olarak "Control and Cybernetics" isimli çalışmada Willem Karek Brauers ve Edmundas Kazimieras Zavadskas tarafından en iti akıllı üretim sisteminin seçimi için uygulanmıştır (Dey vd., 2012). MOORA yönteminin, fayda ve maliyet kriterleri için ayrı ayrı matematiksel hesaplamalar içermesinin, yanında diğer ÇKKV modellerine göre, bir üstünlük sağladığ1 görülmüştür (Yıldırım, 2015). Tedarikçi seçimi probleminde çalışılmıştır (Vatansever ve Uluköy, 2013), bir inşaat projesi için yüklenici seçiminde MOORA yöntemini kullanarak çözüm bulmaya çalışmışlardır. Üretim sektörü için en uygun kurumsal kaynak planlaması yazılımı seçimi için kullanmışlardır (Brauers ve Ginevičius, 2013), yatırım planlama risk değerlendirmede (Özdağoğlu, 2014), işletmelerin karar verme aşamalarında kriterleri değerlendirmek için kullanılmıştır (Parks vd., 2007). Ayrıca ulaşım alanında da uygulamaları vardır (Hamurcu ve Eren, 2021).

\section{Uygulama}

Elektrikli araçlarda, aracın hareketi sadece bataryadan sağlanan elektrik enerjisiyle elektrik motorundan sağlanmaktadır. Bataryaların yavaş şarj olması ve uzun menzilde yetersiz kalması gibi başlıca sebeplerden dolayı elektrikli araçlarda batarya seçimi oldukça 
önemlidir. Bu sebeple elektrikli araçlarda kullanılan batarya teknolojilerinin gelişimi gün geçtikçe artmaktadır. Bu çalışmada, elektrikli araçlarda kullanılmak üzere batarya seçiminde ÇKKV yöntemlerinden olan AHP ve MOORA yöntemi ile alternatif bataryalar arasından seçim yapılmıştır. Bu çalışmada uzman görüşleri doğrultusunda sekiz batarya arasından, kullanıcı perspektifine en uygun dört batarya değerlendirilmiştir.

\subsection{Araştırma Metodolojisi}

Karar verme probleminin belirlenmesi ile başlayan süreçte kriterler ve alternatiflerin belirlenmesinden sonra problem, AHP ve MOORA (oran ve referans noktası) yöntemleri ile çözümü yapılmıştır. Bunun beraberinde AHP ağırlıklı MOORA yöntemi ile çözümü de yapılmıştır. AHP ve MOORA yöntemlerinin adımları sırasıyla gösterilmiştir ve sonuç sıralamaları belirlenmiştir. Araştırma metodolojisi Şekil 2'de verilmiştir. Değerlendirme kriterleri literatür araştırması ve uzman görüşleri doğrultusunda bataryaların özellikleri dikkate alınarak belirlenmiştir. Alternatif bataryalar, 8 batarya teknolojisi arasından uzmanların görüşleri ve akademik çalışmalar temel alınarak 4'e indirilmiştir. Karar sürecinde, akademisyen uzmanların değerlendirmelerine başvurulmuştur. Karar sürecinde önce AHP yöntemi ve MOORA yöntemleri ayrı ayrı uygulanmış ve akabinde AHP-MOORA yöntemleri karma olarak birlikte uygulanmıştır. Uygulamalar sonucunda ortaya çıkan sıralamalar karşılaştırılmıştır.

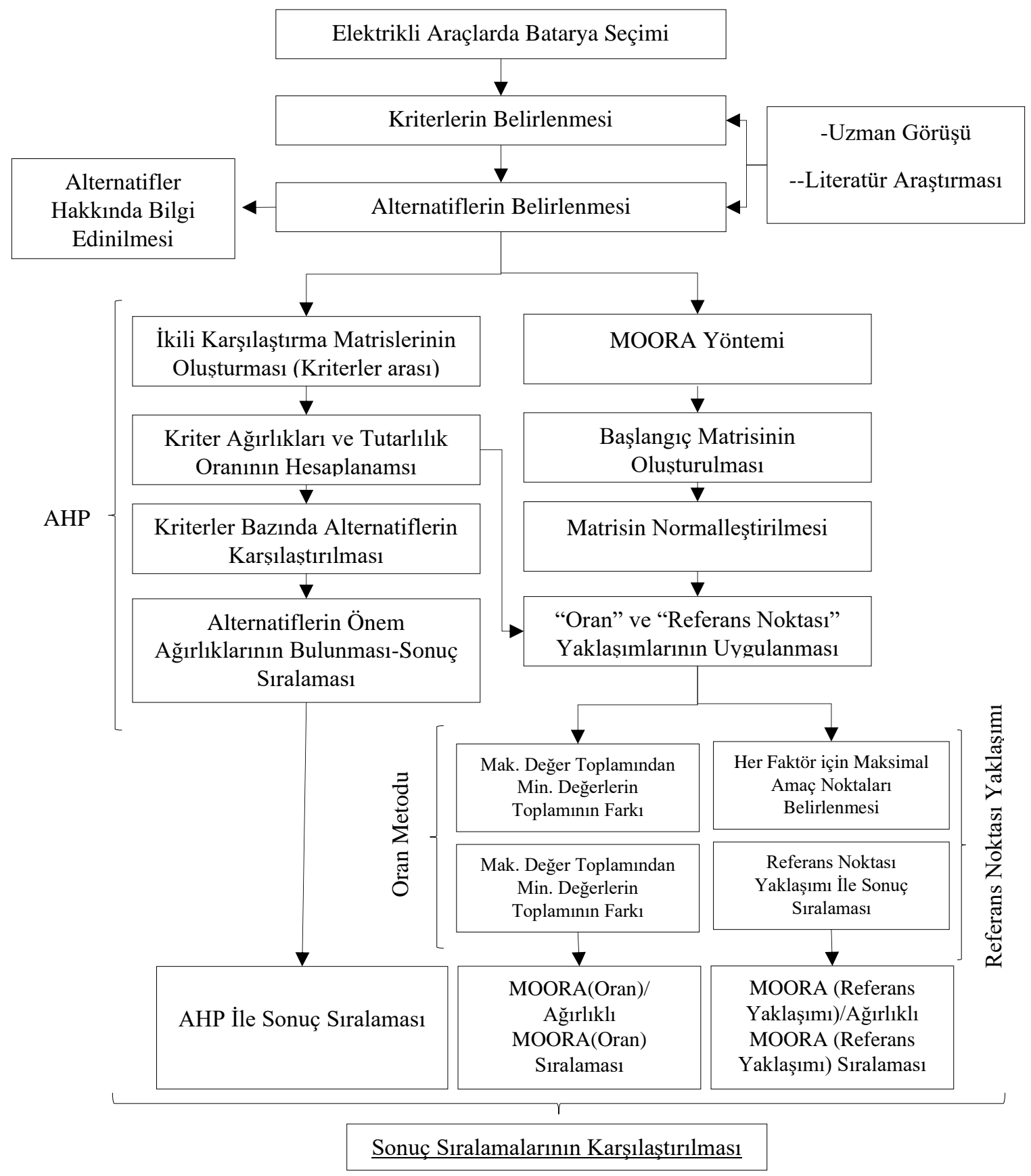

Şekil 2. Araştırma Metodolojisi 
Çevresel endişelerin artması, ekonomik nedenler, fosil enerjinin tükenmesi ile yenilenebilir enerji kaynaklarına yönelimin artması elektrikli araçlara yönelimi hızlandırmıştır. Elektrikli araçların daha kısa menzilleri ve şarj süreleri nedeniyle batarya teknolojilerinin daha da geliştirilmesi gerekliliğini ortaya koymaktadır. Bu kapsamda çeşitlenen ve geliştirilen batarya teknolojileri arasında hem üreticiler hem de tüketiciler bağlamında bir karar verme süreci gerekmektedir. Bu noktada araştırmanın önemi, elektrikli araçların gelişimi için kilit konumda olan bataryaların gelişmesi ve çeşitlenmesiyle beraber elektrikli araçların tercih edilmelerinde artış olacağ beklenmektedir. Dolayısıyla bu çalışma ile gelişen teknoloji ile çeşitlenen batarya teknolojilerinin karşılaştırılması ve sıralanması yapılarak en iyi olan alternatif belirlenmiştir. Ayrıca kullanıcıların araç satın alma süreçlerine yardımcı olabilecek bir karar verme süreci ortaya konulmuştur.

\subsection{Alternatiflerin Belirlenmesi}

Elektrikli araçlar için birçok batarya teknolojisi bulunmaktadır ve gelişim aşamasındadır. Uzman görüşleri doğrultusunda alternatifler belirlenmiştir. Elektrikli araçlarda kullanılmak üzere tercih edilen bataryalar arasından, uzman görüşler doğrultusunda sekiz batarya arasından kullanıcı perspektifine en uygun dört batarya seçilmiştir. Bunlardan en çok tercih edilen bataryalar Pb-asit (Kurşun-Asit), Ni-Cd (Nikel Kadmiyum), Ni-MH (Nikel Metal Hidrat) ve Li-ion (Lityum İyon) pillerdir (Bowkett vd., 2013). Bu sebeple alternatiflerimiz olarak bu dört batarya değerlendirmeye alınmıştır.

\subsection{AHP Uygulamasi}

AHP yöntemi, belirli bir karar hiyerarşisi içinde hedef, değerlendirme kriteri ve alternatifler doğrultusunda ağıllıklandırma veya sıralama yapan Thomas L. Saaty tarafindan 1970 yılında geliştirilen bir karar verme sürecidir (Cao vd., 2008).

Elektrikli araçlarda kullanılmak üzere batarya seçimi probleminde yedi kriter, dört alternatif belirlenmiştir. Kriterler sırasıyla K1(spesifik enerji), K2 (enerji yoğunluğu), K3(elektrik verimliliği), K4(deşarj oranı), K5(nominal gerilim), K6(çevrim) ve K7(dayanıklılık) şeklinde kısaltılarak gösterilmiştir. Yapılan çalışmada Endüstri Mühendisliği (1 profesör, 2 Dr. Öğrt. Üy., 1 Öğretim görevlisi ve 1 araştırma görevlisi) ve Kimya bölümü (1 Doç. Dr. ve 1 Dr. Öğrt. Üy.) öğretim üyelerinden yararlanılmış olup, uzman görüşleri doğrultusunda çalışmanın akışına yön verilmiştir.

\section{Aşama 1. Hiyerarşik Yapının Oluşturulması}

Amaç, kriterler ve alternatifler belirlenerek hiyerarşik yapı oluşturulmaktadır. Yedi kriter, dört alternatif belirlenmiştir. Hiyerarşik yapı Şekil 3'deki gibi oluşturulmuştur.

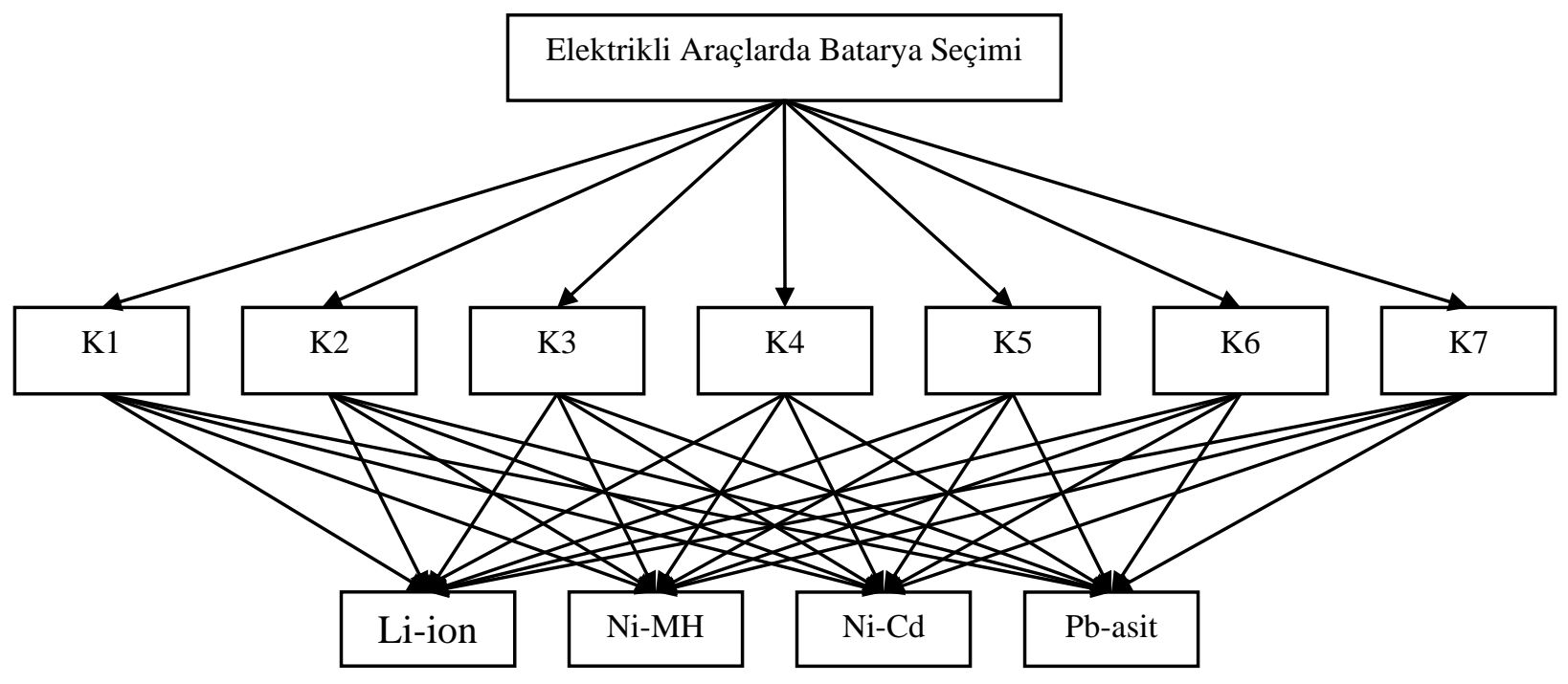

Şekil 3. AHP Hiyerarşik Yapısı

Aşama 2. İkili Karşılaştırmalar Matrisinin Oluşturulması

Hiyerarşik yapı meydana getirildikten sonra kriterlerin göreceli önem derecelerini gösteren ikili karşılaştırma matrisi (üstünlükler belirlenir) hesaplanmaktadır (Garcia-Cascales ve Lamata, 2009). İkili karşılaştırma matrisi nxn boyutunda bir matristir. Aşağıda Tablo 5'de ikili karşılaştırma matrisi gösterilmiştir. 
UMAGD, (2021) 13(2), 733-749, Eren et al.

Tablo 5. İkili Karşılaştırma Matrisi

\begin{tabular}{cccccccc}
\hline Kriterler & K1 & K2 & K3 & K4 & K5 & K6 & K7 \\
\hline K1 & 1 & 7 & 5 & 3 & 3 & 3 & 7 \\
K2 & $1 / 7$ & 1 & 3 & 5 & 5 & 5 & 7 \\
K3 & $1 / 5$ & $1 / 3$ & 1 & 5 & 7 & 5 & 3 \\
K4 & $1 / 3$ & $1 / 5$ & $1 / 5$ & 1 & 3 & 3 & 7 \\
K5 & $1 / 3$ & $1 / 5$ & $1 / 7$ & $1 / 3$ & 1 & 3 & 7 \\
K6 & $1 / 3$ & $1 / 5$ & $1 / 5$ & $1 / 3$ & $1 / 3$ & 1 & 7 \\
K7 & $1 / 7$ & $1 / 7$ & $1 / 3$ & $1 / 7$ & $1 / 7$ & $1 / 7$ & 1 \\
\hline
\end{tabular}

Aşama 3. Kriter Ağırlıklarının Belirlenmesi

Tablo 6' de sütun değerlerinin ortalamaları alınarak kriterler için özvektör hesaplanması gösterilmiştir. Hesaplanan özvektör değerleri kriterlerin ağırlıklarını ifade etmektedir.

Tablo 6. Özvektörün Belirlenmesi

\begin{tabular}{|c|c|c|c|c|c|c|c|}
\hline Kriter & K1 & K2 & K3 & K4 & K5 & K6 & K7 \\
\hline K1 & 0,402 & 0,771 & 0,506 & 0,202 & 0,154 & 0,148 & 0,179 \\
\hline K2 & 0,057 & 0,110 & 0,303 & 0,337 & 0,256 & 0,248 & 0,179 \\
\hline K3 & 0,080 & 0,036 & 0,101 & 0,337 & 0,359 & 0,248 & 0,076 \\
\hline K4 & 0,134 & 0,022 & 0,020 & 0,067 & 0,154 & 0,148 & 0,179 \\
\hline K5 & 0,134 & 0,022 & 0,014 & 0,022 & 0,051 & 0,148 & 0,179 \\
\hline K6 & 0,134 & 0,022 & 0,020 & 0,022 & 0,017 & 0,049 & 0,179 \\
\hline K7 & 0,057 & 0,015 & 0,033 & 0,009 & 0,007 & 0,007 & 0,025 \\
\hline Öz vek. & 0,337 & 0,213 & 0,177 & 0,103 & 0,081 & 0,063 & 0,022 \\
\hline
\end{tabular}

Aşama 4. Tutarlılık Oranının Hesaplanması

(2) numaralı formül kullanılarak tutarlılık oranını (CI) hesaplanmaktadır. Tablo 7'de kriterlerin özvektörleri gösterilmiştir.

Tablo 7. Kriterlerin Özvektörleri

\begin{tabular}{ccc}
\hline Kriterler & Kriterlerin öz vektörleri & Tutarlılık oranını (CI) \\
\hline K1 & 0,337 & \\
K2 & 0,213 & CI $=\frac{K \max -n}{n-1}=0,62007$ \\
K3 & 0,177 & \\
K4 & 0,103 & Tutarlılık oranı (CR) \\
K5 & 0,081 & \\
K6 & 0,063 & $C I$ \\
K7 & 0,022 & \\
$R I$ & 0,004698 \\
\hline
\end{tabular}

Tutarlılık oranı 0,10 'dan küçük çıktığı için matris tutarlıdır, kabul edilir. Tutarlılık oranı kabul edilebilir seviyede ise alternatiflerin öncelik sıralamasına geçilmektedir.

Alternatifler ayrı ayrı yedi değerlendirme kriteri bakımından karşılaştırılarak önem seviyeleri bulunur. Tablo 8'de alternatiflerin kriterler bazında özvektörleri gösterilmiştir ve en büyük değeri alan alternatif seçilmektedir (Dinçer ve Görener, 2011).

Tablo 8. Alternatiflerin Özvektörleri

\begin{tabular}{cccccccc}
\hline \multicolumn{7}{c}{ Alternatiflerin Özvektörleri } \\
\hline Alter. & K1 & K2 & K3 & K4 & K5 & K6 & K7 \\
\hline Li-ion & 0,526 & 0,557 & 0,559 & 0,139 & 0,166 & 0,465 & 0,415 \\
Ni-MH & 0,255 & 0,263 & 0,222 & 0,481 & 0,498 & 0,292 & 0,291 \\
Ni-Cd & 0,151 & 0,121 & 0,086 & 0,243 & 0,241 & 0,196 & 0,057 \\
Pb-asit & 0,066 & 0,056 & 0,131 & 0,136 & 0,093 & 0,045 & 0,236 \\
\hline
\end{tabular}


Alternatiflerin her bir kriter için ikili karşılaştırması yapılır ve ilk dört adım tekrar edilir. Daha sonra her alternatifin, her kriter bazındaki değerini o kriterin ağırlık puanıyla çarparak bulunduğu satır toplanır ve sonuç sıralanır. Tablo 9'da batarya seçim probleminin AHP ile çözümünün önem ağırlıkları ve sonuç sıralaması gösterilmiştir.

Kriterler ve alternatifler arasında yapılan değerlendirmeler, karşılaştırmalar sonucunda en iyi batarya Li-ion pil olarak belirlenmiştir. Yedi kriterin, altısında en iyi batarya Li-ion bataryadır. Deşarj oranının düşük olması tercih sıralamasında önemli bir etken olmasına rağmen diğer kriterler de en iyi olması tercih sıralamasında birinci sırada yer almasını sağlamaktadır. AHP ile çözümü yapılan elektrikli araçlarda batarya seçimi probleminin sonuç sıralaması; Li-ion, $\mathrm{Ni}-\mathrm{MH}, \mathrm{Ni}-\mathrm{cd}$ ve $\mathrm{Pb}$-asit şeklinde sıralanmıştır.

Tablo 9. AHP ile Sonuç Sıralaması

\begin{tabular}{ccc}
\hline Alternatifler & Önem A Ăırlı̆̆ & Sıralama \\
\hline Li-ion & 0,462 & 1 \\
Ni-MH & 0,297 & 2 \\
Ni-Cd & 0,151 & 3 \\
Pb-asit & 0,087 & 4 \\
\hline
\end{tabular}

\subsection{MOORA Uygulamasi}

MOORA metodu uygulanarak, elektrikli araçlarda batarya seçimi probleminin çözümü yapılmaktadır. Bu çalışmada kullanılan veriler, AHP uygulamasında kullanılan verilerle aynıdır. Tablo 2'de veriler gösterilmiştir.

\subsubsection{MOORA Oran Metodu}

MOORA yönteminde farklı alternatiflerin farklı amaçlara karşılık gelen değerlerinden oluşan matrislerin hazırlanması ile başlamaktadır. Oluşturulan matris Tablo 10'da gösterilmiştir.

Tablo 10. Kriter Değerleri

\begin{tabular}{ccccc}
\hline Alt. & Li-ion & Ni-MH & Ni-Cd & Pb-asit \\
\hline K1 & 180 & 70 & 50 & 35 \\
K2 & 180 & 140 & 100 & 70 \\
K3 & 85 & 66 & 90 & 90 \\
K4 & 5 & 30 & 10 & 20 \\
K5 & 3,6 & 1,2 & 1,2 & 2 \\
K6 & 8,6 & 7,5 & 4,5 & 24 \\
K7 & 1200 & 1000 & 2000 & 800 \\
\hline
\end{tabular}

Aşama 1. MOORA metodu ile normalleştirme

Formül (5) ve (6) kullanılarak, $X_{i j}{ }^{*}$ ler bulunur. Burada önemli işlemlerden biri de kriter değerlerinde, max ve min durumlarının belirlenmesidir. Normalleştirilmiş değerler Tablo 11 'de gösterilmiştir.

Tablo 11. MOORA Metodu ile Normalleştirilmiş Değerler

\begin{tabular}{cccccccc}
\hline Alt. & $\begin{array}{c}\text { max } \\
\text { K1 }\end{array}$ & $\begin{array}{c}\text { max } \\
\text { K2 }\end{array}$ & $\begin{array}{c}\text { max } \\
\text { K3 }\end{array}$ & $\begin{array}{c}\text { min } \\
\text { K4 }\end{array}$ & $\begin{array}{c}\max \\
\text { K5 }\end{array}$ & $\begin{array}{c}\max \\
\text { K6 }\end{array}$ & $\begin{array}{c}\max \\
\text { K7 }\end{array}$ \\
\hline Li-ion & 0.888 & 0.695 & 0.509 & 0.132 & 0.808 & 0.319 & 0.450 \\
Ni-MH & 0.345 & 0.541 & 0.395 & 0.794 & 0.269 & 0.278 & 0.375 \\
Ni-Cd & 0.246 & 0.386 & 0.539 & 0.264 & 0.269 & 0.166 & 0.751 \\
Pb-asit & 0.172 & 0.270 & 0.539 & 0.529 & 0.449 & 0.890 & 0.300 \\
\hline
\end{tabular}

Optimizasyon için, değerler en düşük ve en yüksek olma durumlarına göre toplanır. Elektrikli araçlarda batarya seçimi problemini MOORA yöntemi ile çözümünün tercih sıralaması Li-ion, Ni-cd, Ni-MH ve Pb-asit şeklinde belirlenmiştir.

\subsubsection{MOORA referans metodu ile çözüm}

AHP ve MOORA yöntemleriyle ayrı ayrı çözümü yapılmıştır. Daha sonra kriter ağırlıklandırma işlemleri için AHP yöntemi kullanılmıştır. Alternatiflerin sıralanması işlemi ise MOORA yöntemiyle yapılmıştır. Aşağıda Tablo 12' de AHP, MOORA (referansoran) ve bütünleşik AHP-MOORA (referans-oran) yöntemleriyle çözüm sonuçları gösterilmiştir. 
Bu çalışmada elektrikli araçlarda kullanılmak üzere batarya seçimi yapılmıştır. Belirlenen dört batarya arasından kriterler bazında en iyi batarya seçilmiştir. Batarya seçimi AHP, MOORA ve AHP- MOORA ağırlıklı çözümü yapılarak seçilmiştir. MOORA yönteminde referans ve oran metotları ile çözümü yapılmıştır. Beş yöntem ile çözüm sonucunda en iyi batarya Li-ion olarak belirlenmiştir. Sonuçların ilk tercihte birbirini desteklediği ancak diğer sıralarda değişikliklerin olduğu görülmektedir.

Tablo 12. Kriterlere Göre Sonuçlar

\begin{tabular}{|c|c|c|c|c|c|c|c|c|c|c|}
\hline \multirow{3}{*}{ Alter. } & \multirow{2}{*}{\multicolumn{2}{|c|}{ AHP Çözümü }} & \multicolumn{4}{|c|}{ MOORA Çözümü } & \multicolumn{4}{|c|}{ AHP Ağırlıklı MOORA Çözümü } \\
\hline & & & \multicolumn{2}{|c|}{ Referans metodu } & \multicolumn{2}{|c|}{ Oran Metodu } & \multicolumn{2}{|c|}{ Referans metodu } & \multicolumn{2}{|c|}{ Oran Metodu } \\
\hline & $\begin{array}{c}\text { Önem } \\
\text { Ağırlığı }\end{array}$ & Sira & $\mathrm{Y}^{*}$ & Sira & $\mathrm{Y}^{*}$ & Sira & $\mathrm{Y}^{*}$ & Sira & $\mathrm{Y}^{*}$ & Sira \\
\hline Li-ion & 0,462 & 1 & 0,571 & 1 & 3,540 & 1 & 0,036 & 1 & 0,620 & 1 \\
\hline Ni-MH & 0,297 & 2 & 0,662 & 2 & 1,411 & 4 & 0,183 & 2 & 0,268 & 3 \\
\hline Ni-Cd & 0,151 & 3 & 0,723 & 4 & 2,096 & 2 & 0,216 & 3 & 0,283 & 2 \\
\hline Pb-asit & 0,087 & 4 & 0,716 & 3 & 2,093 & 3 & 0,241 & 4 & 0,256 & 4 \\
\hline
\end{tabular}

\section{Sonuç ve Tartışma}

$\mathrm{Bu}$ çalışmada elektrikli araçların tercihinde önemli faktörlerden biri olan batarya seçimi yapılmıştır. Seçim süreci için ÇKKV yöntemlerinden AHP ve MOORA yöntemleri ayrı ayrı ve bütünleşik olarak uygulanmıştır. Ayrıca MOORA yöntemi kendi içinde referans noktası yaklaşımı ve oran metodu kullanılarak tercih sıralamaları yapılmıştı. Sonuçta Li-ion batarya en iyi alternatif olarak ön plana çıkmıştır. Her 4 yöntemde farklı sonuç sıralaması ortaya çıkmıştır; ancak beş yöntemde de Li-ion batarya birinci sırada yer almaktadır. Elektrikli araç üreticileri, her biçimlendirmeye göre en iyi, en ucuz, güvenilir, yüksek kapasiteli bataryayı seçmekte zorlanmaktadırlar. Elektrikli araçlar için batarya seçimi, bu yazıda ele alınmış ve batarya teknolojisinin seçimi metodolojisi önerilmiştir. EA uygulaması için ÇKKV kullanılarak yapılan uygulamada en iyi alternatif Li-ion teknolojisini seçmek olduğu görülmüştür. Li-ion pillerin elektrikli araçlarda baskın kullanım nedenleri; enerji verimliliği, daha uzun ömür ve diğer pillere kıyasla daha hızlı şarj oranıdır. Geliştirilen karar verme metodolojisi sadece batarya seçimi için yararlı değil aynı zamanda diğer çeşitli EA teknolojisinin uygulamaları içinde kullanılabilir.

Yapılan çalışma sonucunda en iyi batarya belirlenmiş olup, elektrikli araçlarda batarya seçim problemine çözüm getirilmeye çalışılmıştır. Elektrikli araçlar ulaşımda alışılagelmiş yakıtlardan farklıdır. Elektrikli araçlarda birçok batarya çeşidi bulunmaktadır. ÇKKV yöntemleri kullanılarak en iyi batarya Li-ion batarya çıkmış olsa da diğer bataryalarda da olduğu gibi Li-ion batarya araştırma aşamasında gelişim göstermektedir. Elektrikli araçlara olan talebin düşük olmasının başlıca sebeplerinde biride bataryalardaki eksikliklerdir. Bataryaların ömrü, dayanıklılık, maliyet vb. gibi özellikleri gelişim gösterdiği sürece bu bataryalara olan ilgi artacaktır. Bunun beraberinde elektrikli araçlara olan talep de artış gösterecektir. Bataryalar ile şarj cihazları üzerinde de önemle durulması gereken bir konudur. Ayrıca şarj istasyonlarının yerlerinin seçimi veya belirlenmesi işlemlerinde de batarya teknolojileri ile uzatılmaya çalışılan araç menzillerine göre güncellenmeler yapılabilir.

Elektrikli araç satın alacak, tercihinde bulunacak kullanıcıların üzerinde durdukları kilit noktalardan biri batarya teknolojileridir. Dolayısıyla bu çalışma ile elektrikli araç satın alma süreçlerine etki edecek batarya teknolojilerinin değerlendirilmesinde kullanıcılara yardımcı olabilecek bir karar verme süreci sunulmuştur.

Büyük otomobil üreticileri de çeşitlenen batarya teknolojiler arasından seçim yapmak için ikilemle karşs karşıya kalmaktadırlar. Tüm bu karmaşaya rağmen otomobil üreticileri batarya konusunda maliyet, güvenlik ve enerji depolama kapasitesi gibi çeşitli parametreler bakımından ürettikleri araçlar için doğru batarya teknolojisini tercih etmeleri gereklidir. Elektrikli araç konsepti üzerinde çalışan üreticiler için doğru batarya seçimi büyük bir öneme sahiptir. Bu çalışma ile elektrikli ve hibrid otomobil üreticilerinin de karar verme süreçleri için yararlanabilecekleri bir kaynak niteliğindedir. Ayrıca batarya teknolojilerinin, kullanıcıların beklentileri doğrultusunda karşılanabiliyor olması elektrikli araçlara olan talebin artmasını da tetikleyecektir.

Gelecek çalışmalarda, kullanılan kriterler tercihlere göre farklılık gösterebilir. Bunun için batarya seçerken istenen amaca uygun olup olmadığ 1 konusunda uygun kriterler belirleyerek VIKOR-TOPSIS-PROMETHEE gibi diğer sıralama yöntemleri ve bütünleşmiş yöntemler kullanılabilir. Ayrıca kriterlerin birbirleri ile ilişkili olduğu durumlarda göz önünde bulundurularak ANP yöntemi ile seçim veya kriter önem ağırlıkları belirlenebilir. Ayrıca kullanıcı perspektifinden yaptığımız bu değerlendirme üretici firmalar tarafından da ortaya konulabilir. Ek olarak bu çalışmada akademisyen uzmanlardan yararlanılmıştır. Gelecek çalışmalarda otomobil mühendisliği alanında mühendis ve uzmanlardan da yararlanılarak grup karar verme uygulamaları gerçekleştirilebilir. 


\section{Referanslar}

Adıgüzel, O., (2009). Personel seçiminin analitik hiyerarşi prosesi yöntemiyle gerçekleştirilmesi, Dumlupınar Üniversitesi, Sosyal Bilimler Dergisi, 24, 243-251.

Ahmadi, M., Mithulananthan, N., Sharma, R., (2016). A review on topologies for fast charging stations for electric vehicles, In International Conference on Power System Technology, IEEE,1-6.

Aktaş, M., Baygüneş, B., Kıvrak, S., Çavuş, B., \& Sözen, F. (2020) Elektrikli Araç İçin Düşük Maliyetli Bir Batarya Yönetim Sistemi Tasarımı ve Gerçekleştirilmesi. Avrupa Bilim ve Teknoloji Dergisi, 227-238.

Battery University, "Retreaved, fromhttp://batteryuniversity.com/learn/article/cost_of_power", 07.30.2014.

Bowkett, M., Thanapalan, K., Stockley, T., Hathway, M., Williams, J., (2013). Design and implementation of an optimal battery management system for hybrid electric vehicles, In international conference on automation and computing IEEE, 1-5.

Brauers, W.K., Ginevičius, R., (2013). How to invest in belgian shares by MULTIMOORA optimization, Journal of business economics and management, 14, 5, 940-956.

Brauers, W.K.M., Ginevicius, R., Podzevko, V., (2010). Regional development in lithuania considering by the MOORA method, Technological and economic development of economy, 16, 4, 613-640.

Brauers, W.K.M., Zavadskas, E.K., (2006). The MOORA method and its application to privatization in a transition economy, Control and Cybernetics, 35, 2, 445-469.

Bulach, W., Schuler, D., Sellin, G., (2018). Electric vehicle recycling 2020: key component power electronics, Waste management \& research, 36, 4, 311 .

Cano, Z.P., Banham, D., Ye, S. , Hintennach, A., Lu, J., Fowler, M., Chen, Z., (2018). Batteries and fuel cells for emerging electric vehicle markets, Nature Energy, 3, 4, 279.

Cao, D., Leung, L, Law, J., (2008). Modifying inconsistent comparison matrix in analytic hierarchy process: A heuristic approach, Decision Support Systems, 44, 944-953.

Chan, C.C., (2013). The rise \& fall of electric vehicles in lessons learned, Proceedings of the IEEE, 206-212, 1828-1930.

Çellek, S., (2013). Sinop-Gerze yöresinin heyelan duyarlılık analizi, Doktora Tezi, Karadeniz Teknik Üniversitesi, Fen Bilimleri Enstitüsü.

Çelen, A., \& Kaba, M.Y. (2021). Elektrikli Araçlarda Kullanılan Silindirik Lityum İyon Bataryaların Soğutulmasının Parametrik İncelenmesi. Frrat Üniversitesi Mühendislik Bilimleri Dergisi, 33(1), 49-61.

Davutoğlu, O.I., Seçkin, G., Kalat, D.G., Yılmaz, T., Ersu, C.B., (2010). Speciation and implications of heavy metal content in surface sediments of Akyatan Lagoon-Turkey". Desalination, 260(1-3),199-210.

Debreceni, T., Balázs, GG., Varjasi, I., (2016). Elektrikli araçlar için misyon profili odaklı akü sistemleri tasarımı, Gelen yenilenebilir enerji uluslararası konferansı ve güç kalitesi, Madrid, İspanya.

Demir, U., Aküner, M.C., (2018). Design and optimization of in-wheel asynchronous motor for electric vehicle, Gazi Universty, Journal of the Faculty of Engineering and Architecture, 33, 4, 1517-1530.

Demir, U., Aküner, M.C., (2018). Elektrikli bir araç için tekerlek içi asenkron motorun tasarım ve optimizasyonu, Gazi Üniversitesi, Mühendislik-Mimarlık Fakültesi Dergisi, 33, 4, 1517-1530.

Deringöz, A., Danışan T. ve Eren T. (2021). Covid-19 takibinde giyilebilir sağlık teknolojilerinin ÇKKV yöntemleri ile değerlendirilmesi. Politeknik Dergisi, 1-1.

Dey, B., Bairagi, B., Sarkar, B., Sanyal, S., (2012). MOORA based fuzzy multi-criteria decision making approach for supply chain strategy selection, International Journal of Industrial Engineering Computations, 3, 4, 649-662.

Dikmen, İ.C., (2018). An overview of battery technologies. UEMK bildiri özetleri kitabı, 974.

Dinç. S., Hamurcu, M. Ve Eren, T., (2018). Kırıkkale-kampüs dolmuş hattı etkinliğinin çok kriterli karar verme ile değerlendirilmesi. Mehmet Akif Ersoy Üniversitesi Fen Bilimleri Enstitüsü Dergisi, 9(Ek (Suppl.) 1), 238-247.

Dinçer, H., Görener, A., (2011). Analitik Hiyerarşi Süreci ve Vikor tekniği ile dinamik performansa: Bankacllık sektöründe bir uygulama, İstanbul Ticaret Üniversitesi, Sosyal Bilimler Dergisi, 19, 109-127. 
Elbir, T., Koca, H., (2013). Bir üniversite yerleşkesi içinde karayolu trafiğinden kaynaklanan hava kalitesinin belirlenmesi, Dokuz Eylül Üniversitesi, Hava Kirliliği Araştırmaları Dergisi, 2, 45-54.

Erhan, K., Ayaz, M., Özdemir, E., (2013). Elektrikli araç şarj istasyonlarının güç kalitesi üzerine etkileri, Akıllı şebekeler ve Türkiye elektrik şebekesinin geleceği sempozyumu, Ankara, 26-27.

Frieske, B., Kloetzke, M., Mauser, F., (2013). Trends in vehicle concept and key technology development for hybrid and battery electric vehicles, World Electric Vehicle Symposium and Exhibition EVS27 IEEE, 1-12.

Garcia-Cascales, M., Lamata, M., (2009). Selection of a cleaning system for engine maintenance based on the analytic hierarchy process, Computers \& Industrial Engineering, 56, 1442-1451.

Gavcar, E., \& Kara, N. (2020). Elektrikli Otomobil Seçiminde Entropi ve TOPSIS Yöntemlerinin Uygulanması. İş ve İnsan Dergisi, 7(2), 351-359.

Gears educational system, (2014). Battey basics: research, test, measure, analyze and select the optimal battery, Retreaved July 30.

Gören, E.(2011). Hibrid ve elektrikli araçlar ile toplu ulaşımda enerji verimliliği.

Guo, S., Zhao, H., (2015). Optimal site selection of electric vehicle charging station by using fuzzy TOPSIS based on sustainability perspective, Applied Energy, 158, 390-402.

Güner, C. (2013). Dışarıdan şarj edilebilen hibrit elektrikli araç ile menzil artırıcı elektrikli araç konseptlerinin karşılaştırmalı analizi, Yüksek lisans tezi, İstanbul Teknik Üniversitesi, Fen Bilimleri Enstitüsü.

Güner, H., (2005). Bulanık AHP ve bir işletme için tedarikçi seçimi problemine uygulanması, Yüksek Lisans Tezi, Pamukkale Üniversitesi, Fen Bilimleri Enstitüsü.

Güven, F., Rende, H., (2017). Elektrikli Araçların Tasarımında Malzeme Seçiminin Önemi, Engineer \& the Machinery Magazine, 58, $689,81-95$

Gür, Ş., Hamurcu, M. ve Eren, T. (2017). Ankara'da Monoray projelerinin analitik hiyerarşi prosesi ve 0-1 hedef programlama yöntemleri ile seçimi. Pamukkale Üniversitesi Mühendislik Bilimleri Dergisi, 23(4), 437-443.

Hamurcu, M., Eren, T., (2018). Yüksek kapasiteli elektrikli otobüslerin seçiminde hibrit çok kriterli karar verme uygulaması", Transist 11. Uluslararası Ulaşım Teknolojileri Sempozyumu ve Fuarı, 1-10.

Hamurcu, M., Eren, T., (2020). Electric Bus Selection with Multicriteria Decision Analysis for Green Transportation, Sustainability, $12(7), 2777,2020$.

Hamurcu, M., \& Eren, T. (2017). Raylı sistem projeleri kararında AHS-HP ve AAS-HP kombinasyonu. Gazi Mühendislik Bilimleri Dergisi (GMBD), 3(3), 1-13.

Hamurcu, M., Alağaş, H. M., ve Eren, T. (2017). Selection of rail system projects with analytic hierarchy process and goal programming. Sigma Journal of Engineering and Natural Sciences, 8(2), 291-302.

Hofman, T., Dai, C.H., (2010). Energy efficiency analysis and comparison of transmission technologies for an electric vehicle, In vehicle power and propulsion conference IEE, 1-6, 2010,

Huo, H, Cai, H., Zhang, Q., Liu, F., He, K., (2015). Life-cycle assessment of greenhouse gas and air emissions of electric vehicles, A comparison between China and the US. Atmos Environ, 108, 107-116.

Huo, H., Cai, H., Zhang, Q., Liu, F., He, K., (2015). Life-cycle assessment of greenhouse gas and air emissions of electric vehicles, A comparison between China and the US. Atmos Environ, 108, 107-116.

Kaymaz, H., \& Demir, M.F.(2020). Elektrikli Otomobiller için Çekiş Motor Tip Seçimi. International Periodical of Recent Technologies in Applied Engineering, 2(1), 35-41.

Kecek, G., Yüksel, R., (2016). Analitik Hiyerarşi Süreci (AHP) ve Promethee teknikleriyle akıllı telefon seçimi, Dumlupınar Üniversitesi, Sosyal Bilimler Dergisi, 49, 46-62.

Kerem, A., (2014). Elektrikli araç teknolojisinin gelişimi ve gelecek beklentileri, Mehmet Akif Ersoy Üniversitesi Fen Bilimleri Enstitüsü Dergisi, 5, 1, 1-13.

Khaligh, A., Zhihao, L., (2010). Battery, ultracapacitor, fuel cell, and hybrid energy storage systems for electric, hybrid electric, fuel cell, and plug-in hybrid electric vehicles: State of the art, Vehicular technology IEEE transactions on, 59, 6, 2806-2814. 
Kılıncçı, Ö., Önal, S.A., (2011). Fuzzy AHP Approach for supplier selection in a washing machine company, Expert systems with applications, 38, 9656-9664.

Mandal, U.K., Sarkar, B., (2012). Selection of best Intelligent Manufac-turing System (IMS) under fuzzy MOORA conflicting MCDM environment, Int J Emerg Technol Adv Eng 2, 9, 301-310.

Manzetti, S., Mariasiu, F., (2015). Electric vehicle battery technologies: From present state to future systems. Renewable and Sustainable Energy Reviews, 51, 1004-1012.

Ogura, K., Kolhe, M.L., (2017). Battery technologies for electric vehicles. In Electric Vehicles: Prospects and Challenges, 139-167.

Ordonez, J., Gago, E.J., Girard, A., (2016). Processes and technologies for the recycling and recovery of spent lithium-ion batteries, Renewable \& sustainable energy reviews, vol. 60pp, 195-205.

Ömürbek, N., Üstündağ, S., Helvacıoğlı, Ö.C., (2013). Kuruluş yeri seçiminde Analitik Hiyerarşi Süreci (AHP) kullanımı: Isparta Bölgesi’nde bir uygulama, Yönetim Bilimleri Dergisi, 11, 21, 101-116.

Özdağoğlu, A., (2014). Normalizasyon yöntemlerinin çok ölçütlü karar verme sürecine etkisi-MOORA yöntemi incelemesi, Ege Akademik Bakış Dergisi, 14, 2, 283-294.

Özkop, E. (2013). Elektrikli araçlar için şarj cihazı.

Öztürk, Z., (2018). İstanbul'da karayolu yolcu taşımacıllğında elektrikli araç kullanımının incelenmesi, El-Cezeri Journal of Science and Engineering, 5, 2, 367-386.

Palaz, H., Kovacı, A., (2008). Türk Deniz Kuvvetleri denizaltılarının seçiminin AHP ile değerlendirilmesi, Havacılık ve Uzay Teknolojileri Dergisi,3, 53-60.

Parks, K., Denholm, P., Markel, T., (2007). Costs and emissions associated with plug-in hybrid electric vehicle charging in the xcel energy colorado service territory, Contract National renewable energy laboratory, USA, 640-41410.

Raslavicius, L., Azzopardi, B., Keršys, A., Starevicius, M., Bazaras, Z., (2015). Makaras, R. electric vehicles challenges and opportunities: Lithuanian review, Renew sustain energy rev. 42, 786-800.

Raslavicius, L., Starevicius, M., Keršys, A., Pilkauskas, K., Vilkauskas, A., (2013). Performance of an all-electric vehicle under UN ECE R101 test conditions, A feasibility study for the city of Kaunas Lithuania Energy, 55, 436-448.

Saaty., T.L., (1990). How to make a decision: the analytic hierarchy process, European journal of operational research, 48, 9-26.

San, R., Momber, T.G., Abbad, M.R., Miralles, A.S., (2011). Regulatory framework and business models for charging plug-in electric vehicles: Infrastructure, agents, and commercial relationships, Energy policy, 39, 10, 6360-6375.

Sarıkurt, T., Balıkçı, A., (2017). Tam elektrikli araçlar için özgün bir enerji yönetim sistemi uygulaması, Gazi Üniversitesi, Mühendislik-Mimarlık Fakültesi Dergisi, 32, 2, 323-333.

Satılmış, O., Meşe, E., (2011). Elektrikli ve hibrit elektrikli araçlar için batarya şarj cihazları.

Sayın, A.A., Yüksel, İ., (2011). Elektrikli aracın, lityum-iyon bataryasının modellenmesi ve batarya yönetimi, Mühendis ve Makine, $52,616,75-82$.

Sierzchula, W., Bakker, S., Maat, K., (2014). Van Wee, B. The influence of financial incentives and other socio-economic factors on electric vehicle adoption, Energy policy, 68, 183-194.

Solera, L., (2001). Nonconventional on-board charger for electric vehicle propulsion batteries, Vehicular Technology IEEE Transactions on, 50, 144-149.

Sun, B., Sun, X., Tsang, D. H., \& Whitt, W. (2019). Optimal battery purchasing and charging strategy at electric vehicle battery swap stations. European Journal of Operational Research, 279(2), 524-539.

Tarlak, H., İşen, E. (2018). Elektrikli Araçlar ve Akü Şarj Sistemleri, 4-1, 124-141.

Taş, M., Özlemiş, Ş. N., Hamurcu, M., ve Eren, T. (2017). Ankara'da AHP ve PROMETHEE yaklaşımıyla monoray hat tipinin belirlenmesi. Ekonomi İşletme Siyaset ve Uluslararası İlişkiler Dergisi, 3(1), 65-89.

TEHAD, (2021). 2021 yılı ilk çeyreğinde, Elektrikli ve Hibrid araç satışları arttı | TEHAD (Erişim tarihi:01.06.2021)

Tunca, M.Z., Aksoy, E., Bülbül, H., Ömürbek, N., (2015). AHP temelli TOPSIS ve ELECTRE yöntemleri ile muhasebe paket programı seçimi, Ömer Halisdemir Üniversitesi, İktisadi ve İdari Bilimler Fakültesi dergisi, 8, 1, 53-71. 
Tuncay, R.N., Üstün, Ö., (2004). Otomotiv elektroniğindeki gelişmeler, 2004.

Uçarol, H., Kural, E., Bahar, D.M., Özsu, E., Elcik, E., Çimen, M.A., Kütük, O.,(2014). Hibrid ve elektrikli araçlar ulaşımda enerji verimliliği için bir alternatif”, TÜBİTAK Marmara Araştırma Merkezi, Enerji Enstitüsü, 2014.

Ustabaş, A.,(2014). Mikro ve makro etkileri yönünden elektrikli otomobiller (Türkiye ekonomisi örneği), xxxvı, 1, 269-291.

Vatansever, K., Uluköy, M., (2013). Kurumsal kaynak planlaması sistemlerinin bulanık AHP ve bulanık MOORA yöntemleriyle seçimi: Üretim sektöründe bir uygulama, Celal Bayar Üniversitesi, Sosyal Bilimler Dergisi, 11, 2, 274-293.

Von, D.P., Rosenstiel, D.F., Heuermann, S., Hüsig,S., (2015). Why has the introduction of natural gas vehicles failed in Germany, Lessons on the role of market failure in markets for alternative fuel vehicles. Energy policy, 78, 91-101.

Vu, H., Tran, N., Choi, W., (2013). A novel hybrid soft switching full-bridge PWM and full-bridge LLC converter for on-board battery charger applications, In international power electronics and motion control conference (IPEMC-ECCE Asia) 2016 IEEE 8th, 24702473.

Xiong, R., Cao, J., Yu, Q., (2018). Reinforcement learning-based real-time power managem.ent for hybrid energy storage system in the plug-in hybrid electric vehicle, Applied Energy, 211, 538-548.

Yazıcı, V., Özdemir, E. (2013). Elektrikli araç şarj yöntemleri.

Yıldırım, B.F., (2015). Çok kriterli karar verme problemlerinde ARAS yöntemi, Kafkas University, Faculty of economics and administrative sciences journal, 6, 9, 285.

Yılmaz, B., Dağdeviren, M., (2010). Ekipman seçimi probleminde Promethee ve Bulanık Promethee yöntemlerinin karşılaştırmalı analizi, Gazi Üniversitesi, Mühendislik-Mimarlık Fakültesi Dergisi, 25, 4, 811-826.

Yong, J.Y., (2015). A review on the state-of-the-art technologies of electric vehicle, its impacts and prospects, Renewable and sustainable energy reviews 49, 365-385. 